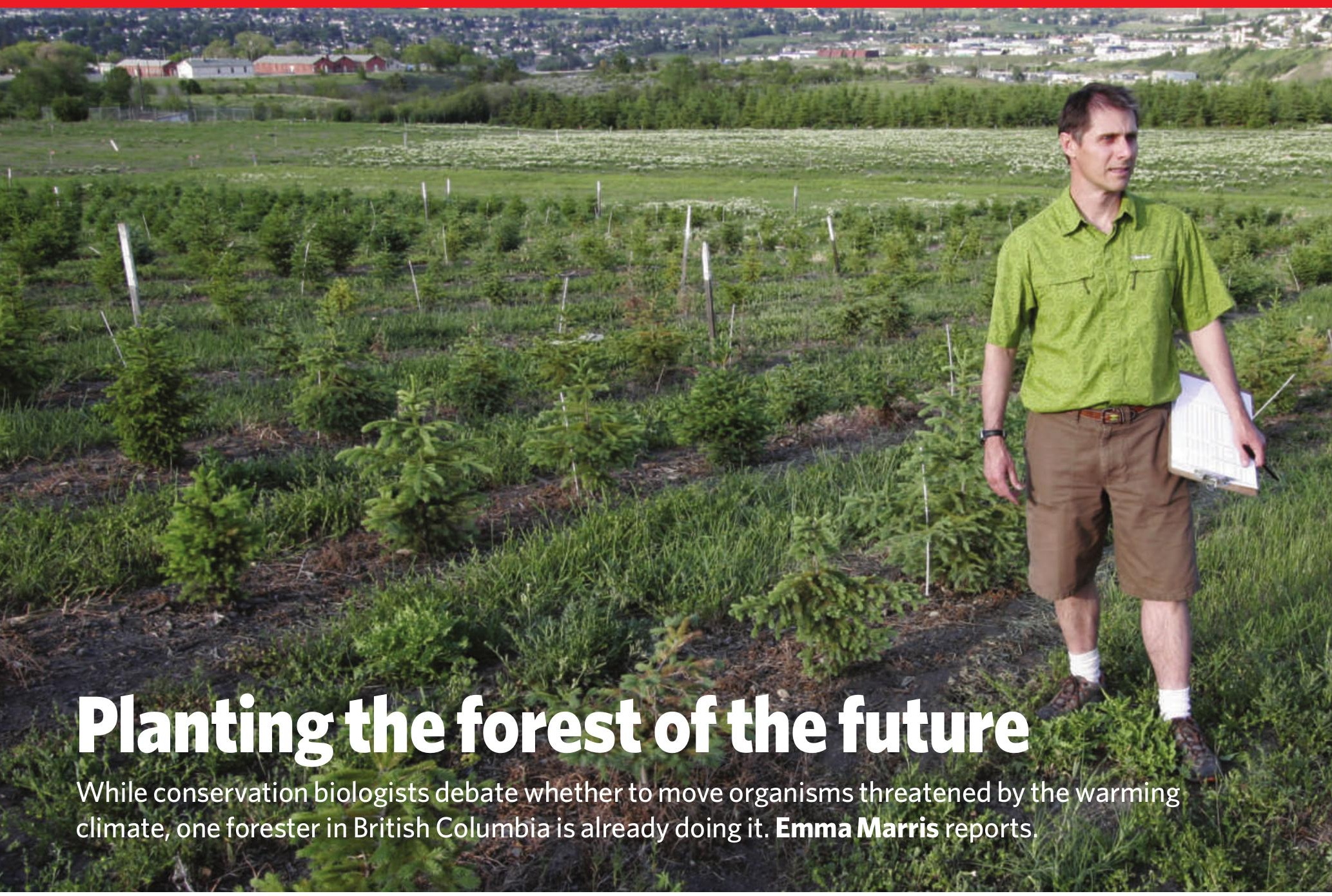

$\Lambda$ $\mathrm{t}$ a research station in the Okanagan valley in British Columbia, a few kilometres outside the town of Vernon, orderly rows of trees run alongside the road. Many of the conifers stand tall and full, producing seeds destined for plantations around the province. But one dusty brown field is filled with lines of seedlings just ankle high. Greg O'Neill, 45, who planted the trees in April, walks among them with a slightly paternal air. They are part of a very slow experiment that will yield the first results that are useful to policymakers just about in time for him to retire.

In a world in which many scientists fret about the toll that global warming is exacting on nature, O'Neill is actually doing something about it. A research scientist for the British Columbia Ministry of Forests, he is moving seedlings to areas that are

and premature. Plants moved by humans may become invasive in their new haunts or just fail to thrive. Yet O'Neill thinks the potential gains in terms of timber production and forest health are worth the risk.

The Canadian province is a pioneer in the field of adaptation, according to Gerald Rehfeldt, a retired United States Forest Service geneticist based in Moscow, Idaho, who has long championed moving trees. "British Columbia is ahead of everybody in the western hemisphere," he says.

O'Neill's experiment is called the Assisted

"Douglas fir grows from
Mexico to British Columbia,
but move it 700 -metres
elevation downhill and you
will be growing toothpicks."
$\quad-$ Greg O'Neill
Migration Adaptation Trial (AMAT) and it is what foresters call a provenance trial. The AMAT is taking seedlings from 40 spots in British Columbia, Washington state, Oregon and Idaho and planting them in 48 sites all over those same outside their current comfort zone to test how they might handle the warmer conditions of the future. And he is behind a government push to move tree populations into new areas to prepare them for the warming climate.

Some hail the policy as pragmatic and forwardthinking, but others label it as dangerous areas. All told, 16 species are involved in the project (see 'Testing assisted migration').

One element of the project tests whether moving trees north will enable them to fare better as the climate changes around them. Another part of the experiment turns the clock forwards on the forests by taking commercially important trees and moving them south, forcing them to endure a warmer climate, quickly simulating years of climate change.

O'Neill expects $50 \%$ of his seedlings to die, mainly because trees are highly diverse genetically and are often adapted to specific local climates. Take a Douglas fir from the coast and bring it inland, and it may well die within a few years. If it doesn't, the chances are that it will be small, pest ridden or crooked. "Douglas fir grows from Mexico City to central British Columbia, but move it 700-metres elevation downhill at any location, and you will be growing toothpicks," says O’Neill.

\section{Warmer woods}

A prototype spruce-only provenance trial on an adjacent patch gives a preview of how some of these seedlings might look in five years. A few are about chest height, others are half or a quarter as tall. Some are dead or half dead, their tops dry and bent into a 'shepherd's crook', invaded by white pine weevil. In general, ones from farther away fare worse.

O'Neill sees a similar pattern at older provenance plantings, some now 50 years old. These trials were planted before climate change was an acknowledged problem. The idea was to see if new combinations of populations and areas could lead to better yields - this works 


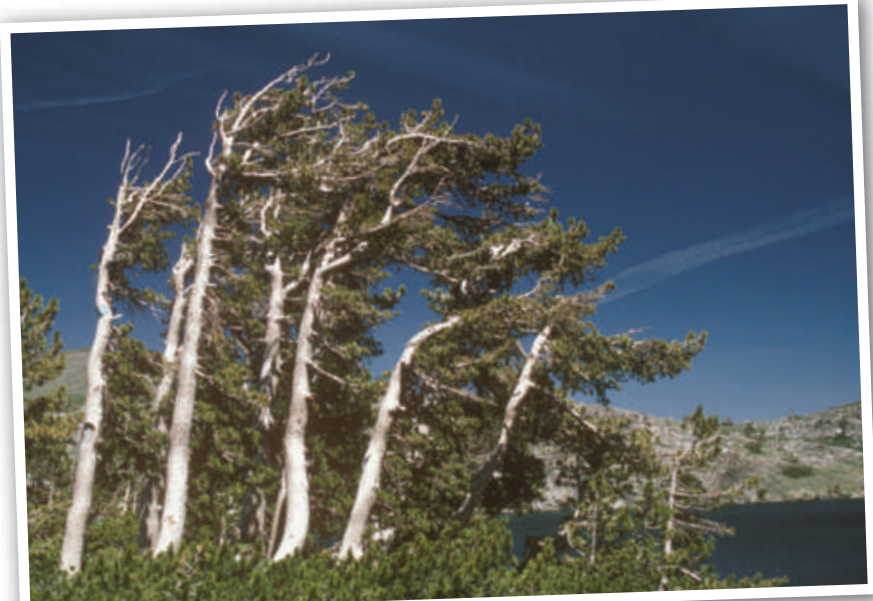

Whitebark pine is threatened by global warming.

the planting site, to account for climate change in the past century and changes anticipated in the first portion of the planted tree's lifetime," says O’Neill.

According to Jim Snetsinger, British Columbia's chief forester, foresters are fans of the change and eager for even more flexibility in policies so that they can chase the climate further. "They're looking for something bigger," he says.

Another potential action would be moving species outside their historical ranges. Neither O'Neill in his AMAT nor forestry companies have gone that far; they are moving populations of trees around within their historical range. But O'Neill says the more substantial movement is a natural extension of what he is doing.

\section{Upping the stakes}

So far, the tree transplanting has happened only with commercial timber. But O'Neill is talking about "taking it to a new level" by putting in the odd hectare of southern seed in places such as parks and extremely remote forests in the province, places not likely to be logged and replanted for a long time, if ever. He's calling the idea "directed diaspora". When the temperature has risen, O’Neill hopes that the genes to adapt trees to the heat will already be circulating. "Why not give them a boost?" he says.

But many conservation biologists think that moving species around is a bad idea. Humans have carted plants and animals all over the globe, intentionally and unintentionally, for millennia. Some of these movements have gone spectacularly badly when the invasive' species have been successful enough to drive native species to extinction, especially on islands and in lakes. Invasive pine species have swamped the diverse fynbos shrublands of South Africa, sucking up the area's water in the process, for example.

The Monterey pine has been on both sides. Its native range includes a tiny sliver of the $\mathrm{Cal}$ ifornia coast and a couple of islands off Baja Cal- ifornia in Mexico, where it is considered to be threatened by development and by an invasive tree disease. But the pine has itself turned into an invader in Australia, South Africa and several other Southern Hemisphere countries, where it was planted for timber.

Daniel Simberloff, an ecologist at the University of Tennessee in Knoxville specializing in invasion biology, calls British Columbia's programme "a waste of time". He sees the whole notion of assisted migration as a bandwagon that has lately become chic. He is less worried about moving populations within the historical range of a species than with moving a species beyond its range. But O'Neill's AMAT trial won't be able to inform policy for a long time, says Simberloff. "He'll be dead before there are any real data from this." Meanwhile, Simberloff says, there is just too great a chance that the translocated trees, or the diseases they host, will become invasive. "I would want to know a lot more about pathogens and insects before I moved things," he says. "There is very little evidence that it is going to help, and in addition there are potential downsides."

So far, critics have either not noticed policy changes in British Columbia or felt that they have yet to cross a line. "We haven't heard anything negative from anyone," says Snetsinger.

Moving trees is also being mooted in Europe. But, Csaba Mátyás, a forestry researcher at the University of West Hungary in Sopron, says he hasn't seen scientific concern spill over into action yet. Nevertheless, he and his European colleagues are pressing for change. And he suggests that the European public won't be very worried about moving populations or spe-

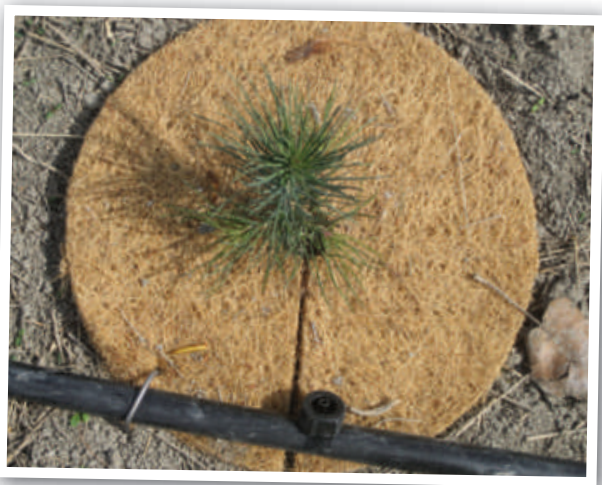

A seedling planted this year in British Columbia. cies around. "This is not an issue in Europe," he says, "as this has been done by foresters for centuries."

Although conservationists are often opposed to moving species, some have started to reconsider assisted migration (also called managed relocation and assisted colonization). Some conservationists see it as the only way to save some slow-moving species from climate change. The idea has been proposed for the California quino checkerspot butterfly and the whitebark pine, whose seeds are an important food for some bear species. But among even the most vocal proponents of this tactic, some think that O'Neill is going too fast.

"This experiment is wonderful, I am glad he is doing it," says Dov Sax, an ecologist at Brown University in Providence, Rhode Island. But, he says, the idea of moving seeds into natural forests gives him the shivers. "The thought of planting a couple of hectares of trees far to the north of where people currently harvest - that sounds a little scary to me." Sax calls for more study, and no precipitous moves. But he admits that his call for caution is as predictable as O'Neill's eagerness to move ahead. "You can see why people with a commercial interest are going to want to find a solution as quickly as possible. Conservationists, who have seen experiments go awry, are going to be more cautious."

The nervousness of conservation biologists and ecologists can also be partly explained by the fact that their subjects and, often, their passion, are ecosystems and all the co-evolved interactions that compose them. Although they want to save species from extinction, ideally they want to save species by saving ecosystems. When trees from farther south suddenly appear, the ecosystem has changed, even if no species are harmed.

In the end, if O'Neill decides to move trees as he would like, it won't matter much what conservationists decide. Even if his directed diasporas are banned from some tracts of land, those protected areas will still be assailed by the spread of seeds and a haze of lime green pollen drifting from commercial plantings. Emma Marris writes for Nature from Columbia, Missouri.

1. www.for.gov.bc.ca/hfp/mountain_pine_beetle/facts.htm 2. Hamann, A. \& Wang, T. Ecology 87, 2773-2786 (2006). 3. Rehfeldt, G. et al. Int. J. Plant Sci. 167, 1123-1150 (2006).

4. Easterling, W. E. et al. Food, fibre and forest products. in Climate Change 2007: Impacts, Adaptation and Vulnerability. Contribution of Working Group II to the Fourth Assessment Report of the Intergovernmental Panel on Climate Change (eds Parry, M. L., Canziani, O. F., Palutikof, J. P., van der Linden, P. J. \& Hanson, C. E.) 273-313 (Cambridge University Press, 2007) 